DOI https://doi.org/10.30525/978-9934-26-038-4-13

\title{
ОЦІНЮВАННЯ ЕФЕКТИВНОСТІ ПРОГРАМИ ФІЗИЧНОЇ ТЕРАПІЇ ЗА ДИНАМІКОЮ РУХОВИХ ПОРУШЕНЬ У ПАЦІЕНТІВ 3 ХВОРОБОЮ ПАРКІНСОНА ТА СТАРЕЧОЮ АСТЕНIЕЮ
}

\author{
Дідоха I. В. \\ аспірант кафедри фізичної терапії, ерготерапії \\ Прикарпатський національний університет імені Василя Стефаника \\ м. Івано-Франківськ, Україна
}

Вступ. Хвороба Паркінсона (ХП) - це хронічне прогресуюче захворювання, спричинене ураженням медіаторного апарату екстрапірамідної системи. Серед нейродегенеративних захворювань по частоті виявлення у осіб похилого віку ХП займає друге місце після хвороби Альцгеймера [4, с. 201]. Більшість досліджень зазначають відносну стабільність захворюваності ХП та тенденцію до збільшення розповсюдженості (1700 випадків на 100000 населення серед осіб старше 65 років), пов'язану із «постарінням» населення в цілому та покращенням виживання пацієнтів з ХП [3].

Моторні та немоторні порушення у пацієнтів з ХП призводять до значного погіршення психосоціального функціонування, міжособистісних відносин та фізичного здоров'я, будучи предикторами низької якості життя [5, с.31]. Тому застосування засобів немедикаментозної реабілітації, зокрема, фізичної терапії, обгрунтовується потребою у корекції порушень, які виникли унаслідок хвороби та асоційованих із похилим віком змін (геріатричних синдромів - старечої астенії, саркопенії, тощо [6, с. $1163 ; 1$, с. 282$)$, а також профілактикою супутніх негативних станів - у першу чергу, високого ризику падіння [2, с. 3599].

Мета роботи: оцінити динаміку моторних розладів у осіб з хворобою Паркінсона та старечою астенією під впливом засобів фізичної терапії.

Матеріали і методи. У дослідженні прийняли участь 57 осіб похилого віку, стадія ХП 2,0, 2,5, 3.0 за Hoehn та Yahr, корегована індивідуальною схемою медикаментозних препаратів, які були поділені на дві групи методом простої рандомізації. Основну групу 1 (ОГ1) склали 29 осіб (18 чоловіків, 11 жінок) віком $65,7 \pm 3,2$ років 3 діагностовано ХП та старечою астенією (СА), які проходили лікування та реабілітацію в поліклінічних умовах згідно принципів клінічного протоколу надання медичної допомоги хворим на хворобу Паркінсона. Основну групу 2 (ОГ2) склали 28 осіб (18 чоловіків, 10 жінок) віком 68,12 $\pm 1,1$ років 
3 діагностованими ХП та СА, які проходили реабілітацію із застосовуванням програми фізичної терапії (ФТ), апробованої у даному дослідженні.

Розроблена програма ФТ тривала 6 місяців. ÏÏ метою було: підтримка загальної рухової активності; підвищення сили і гнучкості м'язів; полегшення ініціації рухів; покращення рухливості суглобів; підтримка правильної постави; покращення ходьби та підтримки рівноваги; профілактика больових синдромів та контрактур; профілактика дихальних порушень; пристосування до змінених умов щоденної активності. У програмі застосовували методи кінезітерапії, ерготерапії, масаж, модифікацію харчування.

Моторні розлади оцінювали за II («Моторні аспекти повсякденного життя») та III («Моторні функції») частинами Уніфікованої шкали оцінки ХП Міжнародного товариства розладів рухів (MDS Unified Parkinson's Disease Rating Scale (MDS-UPDRS)). Оцінювання побутової і повсякденної активності пацієнта з ХП здійснювали за шкалою Шваба - Інгланда (Schwab та England, 1969).

Результати та їх обговорення. Первинне обстеження пацієнтів 3 комобідністю ХП та СА виявило зниження рівня повсякденної активності та погіршення рухових функцій за всіма підпунктами II та III розділів шкали MDS-UPDRS на рівні легких, помірних та середніх порушень (табл. 1). Моторні порушення у поєднанні із м'язовою слабкістю, асоційованою із СА, на фоні дискінезії значно знижують можливість виконання рухів повсякденного самообслуговування, особливо пов'язаних із складнокоординаційними рухами рук та різкою зміною положення тулуба.

Таблиця 1

Динаміка оцінювання шкал MDS-UPDRS у осіб похилого віку з ХП та СА під впливом програми ФТ $(\mathrm{X} \pm \mathrm{S})$

\begin{tabular}{|c|c|c|c|c|}
\hline \multirow{2}{*}{$\begin{array}{c}\text { Критерій } \\
\text { шкали, бали }\end{array}$} & $\begin{array}{c}\text { Первинне } \\
\text { обстеження }\end{array}$ & $\begin{array}{c}\text { Повторне } \\
\text { обстеження }\end{array}$ & До ФТ & Після ФТ \\
\hline \multicolumn{5}{|c|}{ Розділ ІІ. Повсякденна активність } \\
(«Моторні аспекти повсякденного життя) \\
\hline Середній бал & $2,38 \pm 0,069$ & $2,26 \pm 0,074$ & $2,36 \pm 0,089$ & $1,96 \pm 0,057$ \\
\hline \multicolumn{5}{|c|}{ Розділ III. Рухові (моторні) функції } \\
\hline Середній бал & $2,30 \pm 0,087$ & $2,13 \pm 0,095^{\circ}$ & $2,29 \pm 0,113$ & $1,90 \pm 0,089$ \\
\hline
\end{tabular}

Примітки (тут $i$ далі у тексті): ${ }^{\circ}-p<0,05$ - статистично значуща різниия між відповідними параметрами при первинному та повторному обстеженнях;

- $p<0,05$ - статистично значуща різниия між відповідними параметрами ОГІ та ОГ 2 
Результати прицільного оцінювання побутової та повсякденної активностей хворих з поєднанням ХП та СА за шкалою Schwab-England засвідчили, що при початковому обстежені рівень їх можливостей був достатньо низьким (рис. 1). Діапазон оцінювання визначався межами 40\%-80\%, з найбільшою кількістю (більше третини) представників 3 результатом 60\%. Середній бал за шкалою Schwab-England при первинному обстеженні у осіб ОГ1 становив $59,66 \%$, у осіб ОГ $2-58,93 \%$ $(\mathrm{p}>0,05)$.

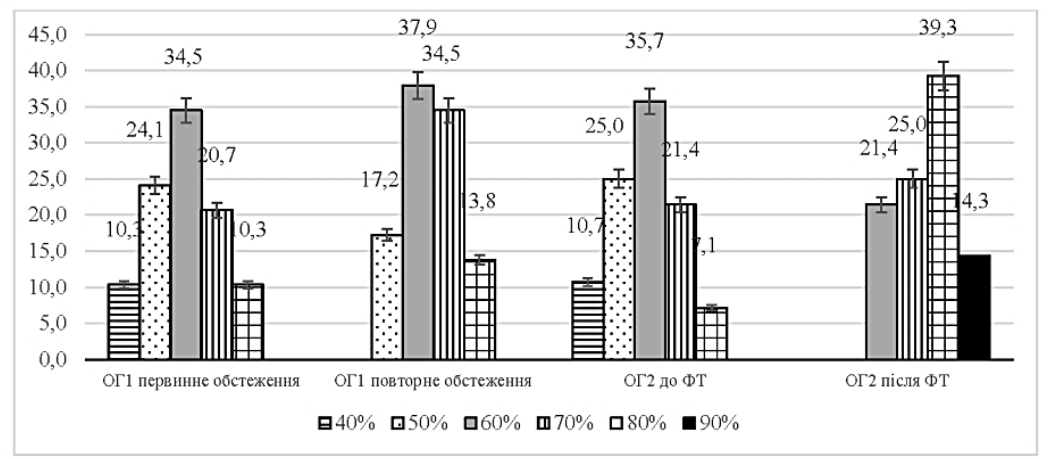

Рис. 1. Динаміка структури результатів оцінювання побутової та повсякденної активності осіб́ похилого віку з ХП та СА під впливом програми ФТ за шкалою Schwab-England, кількість осіб у \% згідно критеріїв оцінювання

За результатами первинного обстеження представники ОГ1 та ОГ2 статистично не відрізнялись між собою (p>0,05), тобто були співставимими. Це дало можливість проводити наступне дослідження, спрямоване на корекцію виявлених порушень.

При повторному обстеженні встановлено, що за шкалою MDSUPDRS у осіб похилого віку з ХП та СА відбулося покращення стану рухової сфери за середніми балами II та III розділів (табл. 1). Але у представників ОГ1 воно склало сумарно за I розділом $5,03 \%$, за II розділом $-7,09 \%$, балансуючи на межі статистичної достовірності, хоча за окремими пунктами було досягнуто статистично значуще покращення відносно вихідного результату. У осіб ОГ2 відповідне покращення досягло відповідно $16,98 \%$ та $16,87 \%$ (р<0,05 відносно вихідного результату та параметрів ОГ1) за рахунок більшої кількості підпунктів, за якими було досягнуто покращення, та вищого оцінювання за них. Пацієнти цієї підгрупи досягнули кращого рівня основних рухів, постуральної стійкості в спокої та під час ходи, часткового самоконтролю дискінезій, що полегшило побутову та повсякденну активність 
Даний факт стверджено на основі покращення результатів оцінювання за шкалою Schwab-England (рис. 1). Середній бал в ОГ1 при повторному обстеженні становив 66,55\% (покращення на 6,9\%), в ОГ 2 - 74,64\% (покращення на $15,71 \%, \mathrm{p}<0,05$ відносно вихідного результату та параметрів ОГ1). В обох групах про повторному обстеженні не виявлялось осіб з виконанням побутової та повсякденної активності на $40 \%$, а в ОГ 2 - ще й $50 \%$. В той же час в останній підгрупі з'явились пацієнти з рівнем виконання активності на 90\%.

Висновки: У пацієнтів похилого віку 3 хворобою Паркінсона та старечою астенією виявлені моторні порушення, погіршення активності повсякденного життя та побутової активності i, як наслідок, зниження якості життя, що стверджено на основі результатів шкал MDSUPDRS, Schwab-England. Розроблена програма фізичної терапії, створена 3 точки зору пацієнтоцентричної моделі реабілітації із застосуванням функціонального тренування, терапевтичних вправ, масажу, ерготерапії, корекції харчування виявила статистично значуще кращий вплив на показники моторних функцій та якості життя у порівнянні із загальною поліклінічною програмою за усіма досліджуваними показниками $(\mathrm{p}<0,05)$.

\section{Література:}

1. Коваль Н.П., Аравіцька М.Г. Ефективність корекції показників ризику падіння та фізичного статусу в осіб похилого віку з старечою астенією та метаболічним синдромом засобами фізичної терапії. Український журнал медицини, біології та спорту. 2020. №5(6). С. 282-291. https://doi.org/10.26693/jmbs05.06.282

2. Byrchak V., Duma Z., Aravitska M. Effectiveness of the active physical therapy in restoring wrist and hand functional ability in patients with immobility-induced contracture of the wrist joint complicated by median nerve entrapment owing to distal forearm fracture. Journal of Physical Education and Sport. 2020. № 20 (6). P. 3599-3606. DOI:10.7752/jpes.2020.06485

3. European Physiotherapy Guideline for Parkinson's Disease, 2014. https://www.parkinsonnet.nl/app/uploads/sites/3/2019/11/eu_guideline_parki nson_guideline_for_pt_s1.pdf

4. Hosseinzadeh A., Khalili M., Sedighi B., Iranpour S., Haghdoost A.A. Parkinson's disease and risk of hip fracture: systematic review and metaanalysis. Acta Neurol Belg. 2018. 118(2). P. 201-210. doi: 10.1007/s13760018-0932-x.

5. Ramazzina I., Bernazzoli B., Costantino C. Systematic review on strength training in Parkinson's disease: an unsolved question. Clinical Interventions in Aging. 2017. 31. 12. P. 619-628. DOI: 10.2147/CIA.S131903. 
6. Vermeiren S. et al. Frailty and the Prediction of Negative Health Outcomes: A Meta-Analysis. Journal of the American Medical Directors Association. 2016. 17(12). P. 1163-1163. DOI: 10.1016/j.jamda.2016.09.010.

DOI https://doi.org/10.30525/978-9934-26-038-4-14

\title{
СЬОГОДЕННЯ ПРОБЛЕМАТИКИ ГОСТРОГО ХОЛЕЦИСТИТУ, УСКЛАДНЕНОГО ПЕРИТОНІТОМ
}

\author{
Запорожченко Б. С. \\ доктор медичних наук, \\ професор кафедри хірургї № 2 \\ Одеський національний медичний університет
}

Кравець К. В.

аспірант кафедри хірургї̈ № 2

Одеський національний медичний університет

Бородаєв. I. Є.

кандидат медичних наук,

дочент кафедри хірургї № 2

Одеський національний медичний університет

Качанов В. М.

кандидат медичних наук,

доиент кафедри хірургї̈ № 2

Одеський національний медичний університет

\section{Зубков О. Б.}

доктор медичних наук, професор кафедри хірургї̈ № 2

Одеський національний медичний університет м. Одеса, Украӥна

Вступ. Друге місце серед хірургічних захворювань в Україні займає гострий холецистит (ГХ). Незважаючи на помітне удосконалення технологій, наукові надбання, кількість медикаментів та поліпшення результатів лікування, летальність після екстрених операцій (9,4-37\%) 